Kalpa Publications in Computing

Volume 12, 2019, Pages 342-356

Proceedings of 4th International Conference on the

Internet, Cyber Security and Information Systems 2019

\title{
Dimensions of perceived risk of mobile banking apps: An empirical investigation of South African retail banking customers
}

\author{
Philile Thusi \\ University of Johannesburg, College of Business and Economics, Department of Marketing \\ Management, Auckland Bunting Road Campus, \\ K Red 6. Auckland Park, Johannesburg. \\ phililet@uj.ac.za, \\ Daniel K. Maduku \\ University of Johannesburg, College of Business and Economics, Department of Marketing \\ Management, Auckland Kingsway Campus, C-Ring 604. Auckland Park, Johannesburg. \\ dmaduku@uj.ac.za
}

\begin{abstract}
Banking transactions carried out in the uncertain conditions of mobile commerce involve high levels of perceived risk and require substantial levels of trust. Therefore, gaining customer trust and reducing the influence of risk is imperative to developing and nurturing long-lasting and strong relationship between customers and retail banks. However, limited research is currently investigating the effects of overall perceived risk and trust on retail banking customers use of mobile commerce, particularly from the perspective of emerging African economies. This study investigates the effects of perceived risk and institution-based trust on the use of mobile banking apps among South African retail bank customers. The model was tested using responses obtained from 352 users of the mobile banking services of the five major retail banks (ABSA, Capitec, FNB, Nedbank, and Standard Bank) in South Africa. The findings of this study suggest that institution-based trust has a significant positive influence on use behaviour of mobile banking apps. Furthermore, perceived risk has a significant negative influence on use behaviour; and, lastly, institution-based trust is found to have a significant negative influence on perceived risk.
\end{abstract}

Key words/ phrases: South Africa, Perceived risk, Mobile banking apps, Institution-based trust, 
Use behavior.

\section{INTRODUCTION}

The advent of the "Internet of Things" have fuelled the shift from traditional financial service delivery modes toward autonomous delivery channels, this has created astonishing opportunities for banks to interact, serve, and build sustainable relationships with their customers (Maduku, 2016). These innovative and novel technologies allow retail banks and their customers to interact using a mobile device. Customers use their mobile devices remotely to access banking networks, known as "mobile banking". The introduction of mobile banking offers even greater convenience to customers (Afshan and Sharif, 2016), a recent approach to the provision of mobile banking services by retail banks is through mobile banking applications ('mobile banking apps') (Moser, 2015).

These apps allow customers to carry out tasks such as making payments, viewing account balances, buying pre-paid airtime, budgeting, and much more (Poromatikul, De Maeyer, Leelapanyalert, Zaby, 2019). The phenomenon is so important that information systems professionals have labelled it as one of the most promising and significant developments in the field of mobile commerce and banking industry (Moser, 2015). Indeed, retail banks have exploited the opportunities provided by this innovation by investing significantly in providing enhanced mobile-based banking services that streamline their processes, reduce operating cost and improve customers experience (Erl, Gee, Chelliah, Kress, Normann, Maier \& Wik, 2014; Fjermestad \& Robertson, 2015).

Nonetheless, mobile banking is still at its early stages of adoption and the concept requires more research, predominantly in developing countries that have been slow to accept this innovation (Farah, Hasni,Abba, 2018). Low levels of customer trust and high levels of perceived risk associated with mobile banking are widely cited as common barriers to the rapid acceptance and use of mobile banking services (Gu, Lee \& Suh, 2010; Alalwan, Dwivedi, Rana \& Williams, 2016; Farah, Hasni, Abba, 2018). McKnight, Choudhury and Kacmar (2002) state that even though all banking transactions require some level of trust, those that are carried out within the uncertain and impersonal circumstances of mobile commerce and electronic commerce require significant levels of trust, owing to the high level of perceived risk frequently linked with online transactions.

Given the critical need for trust and the high levels of risk in mobile commerce, research into the impact of institution-based trust on the acceptance of technology has increased lately (Maduku, 2016; Gao \& Waechter, 2015; Li, Jiang \& Wu, 2014) and the impact of perceived risk on electronic commerce adoption (Arvidsson, 2014; Cruz, Neto, Murioz-Gallego \& Laukkanen, 2010; Park \& Tussyadiah, 2016). 
Despite the growing research interest in mobile commerce trust and risk associated with online transactions, the majority of these studies have been carried out in Western and Asian countries (Srivastava \& Manoj Kumar, 2017; Fara et al., 2018; Poromatikul et al., 2019). The research finding from these studies may not be applicable to retail banking customers from developing countries, particularly in Africa (Huang, Ba \& Lu, 2014). Indeed, Maduku (2016) emphasises that consumers in different countries and cultures have diverse expectations of institutional trust towards mobile banking transactions. Furthermore, consumers in different countries have varied perceptions of the risks of mobile banking. Therefore, research is needed that looks into the dimensions of perceived risk and institutional trust, and their effect on the use of mobile banking apps in developing countries. By highlighting the impact of institution-based trust on the overall risk and the influence of institutionbased trust and perceived risk on customers' use behaviour, the findings of this study will enable retail banks to devise strategies that will increase consumers' institution-based trust and reduce the influence of risk, thereby fostering customer acceptance and use of mobile banking apps. This study also contributes to the limited body of literature on the effects of consumers' institutional trust and the effect of perceived risk on electronic commerce acceptance in Africa.

The rest of this study is arranged as follows: the next section presents the literature review, the research model with its related hypotheses. The third section presents the research methodology used in obtaining data for the study. The fourth section presents the results of the analysis and lastly the discussion of the results and implications.

\section{Literature review}

\subsection{Mobile banking apps}

'Mobile apps' refers to end-user software applications that are installed in mobile devices and that allow users to execute a wide range of financial, entertainment, gaming, and other services (Moser, 2015). From a banking viewpoint, mobile apps are used by banks to offer a range of banking services through a mobile device. In the banking context, mobile apps are referred to as 'mobile banking apps' or ' $m$-banking apps' (Sampaio, 2015). The mobile banking app is the advanced mode of banking that permit users to manage their finances remotely, pay their bills, transfer funds, and buy prepaid airtime when and where it suits them (Fenu \& Pau, 2015). According to the Banking Association of South Africa (2017), mobile banking apps are the future of the banking industry, hence the rapid growth in the use of these apps (Bain and Company, 2015). In order to remain competitive and attract more customers, South African retail banks have introduced value-added services to their mobile banking apps. For instance, the Capitec banking app has numerous 
value-added features, such as SARS e-filing, the capability to stop and block debit orders, requesting e-stamped statements, and buying prepaid airtime in bulk (BusinessTech, 2017). Nevertheless, the success of this innovation rests on its adoption and use by customers (Tan \& Lau, 2016). Banks therefore have a vested interest in promoting its rapid acceptance (Deloitte, 2013).

\subsection{Perceived risk}

According to Lafraxo, Hadri, Amhal and Rossafi (2018), the negative consequences that may arise from customers' actions lead to an important and well-established concept in consumer behaviour: 'perceived risk'. There is an ample consumer behaviour literature on perceived risk, explaining users' evaluation of innovations and consequent purchase decisions. Earlier studies (Lafro et al., 2018; Cocosila \& Trabelsi, 2016; Khasawneh, 2015) confirm a negative association between perceived risk and the acceptance of technology innovations. Studies (Featherman \& Pavlou, 2003; Cocosila \& Trabelsi, 2016; Srivastava \& Kumar, 2017; Chavali \& Kumar, 2018) reveal that different types of risk are perceived by the consumer: performance risk, social risk, financial risk, time risk, privacy risk, psychological risk, and device risk.

Performance risk refers to the losses incurred by deficiencies or malfunctions in a mobile banking app (Grewal, Gotlieb \& Marmorstein, 1994; Srivastava \& Kumar, 2017). Privacy risk refers to the potential loss due to fraud, which compromises the mobile banking user's security (Featherman \& Pavlou, 2002). Time risk refers to the loss of time through any inconvenience that is caused by delays in receiving payments or difficulties in navigating the mobile banking app (Featherman \& Pavlou, 2002). Social risk denotes the potential loss of status in a social group as a result of accepting or using a product or service (Featherman \& Pavlou, 2002; Srivastava \& Kumar, 2017). Financial risk refers to the potential of losing money through transaction errors or bank account misuse. (Featherman \& Pavlou, 2002). Park and Tussyadiah (2016) define device risk as the potential loss through the unreliable technology infrastructure of a mobile service. Featherman \& Pavlou, (2002) define psychological risk as "probable loss of self-esteem and ego frustration linked to the lack of fulfilment of the consumer's purchasing goal. Consumers feel foolish if they purchase a non-performing product and may experience negative feelings that undermine their self-image" In this study, the perceived risk is viewed as the performance risk, financial risk, device risk, privacy risk, and psychological risk. 


\subsection{Institution-based trust}

There has been strong interest in the concept of 'trust' in the risk literature for some time (Maduku, 2016). Through various approaches, a series of studies demonstrate that trust has considerable influence over the perception of risk (Pavlou \& Gefen, 2004; Joubert \& Belle, 2009). With very few exceptions, researchers have consistently argued that trust is a significant factor in risk perception. Of the trustrelated concepts that have developed in the risk literature, institution-based trust stands out as the most significant concept in complicated circumstances. Institution-based trust denotes "the sense of security that a person develops about a situation owing to the guarantees, safety nets, protective mechanisms and other structures" (Maduku, 2016:535). In mobile banking, institution-based trust refers to customers' perceptions of the effectiveness of the mechanisms used by banks to facilitate successful mobile banking transactions.

Figure 1 presents the conceptual model used in this study. The conceptual model posits the risk facets (financial, performance, privacy, device and psychological risk) as the first order constructs and perceived risk and institution-based trust as the direct determinants of mobile banking app use. Moreover institution-based trust is hypothesised to be directly associated with perceived risk. The interactions between the constructs in the conceptual model are discussed below.

\section{Figure1: Conceptual model}

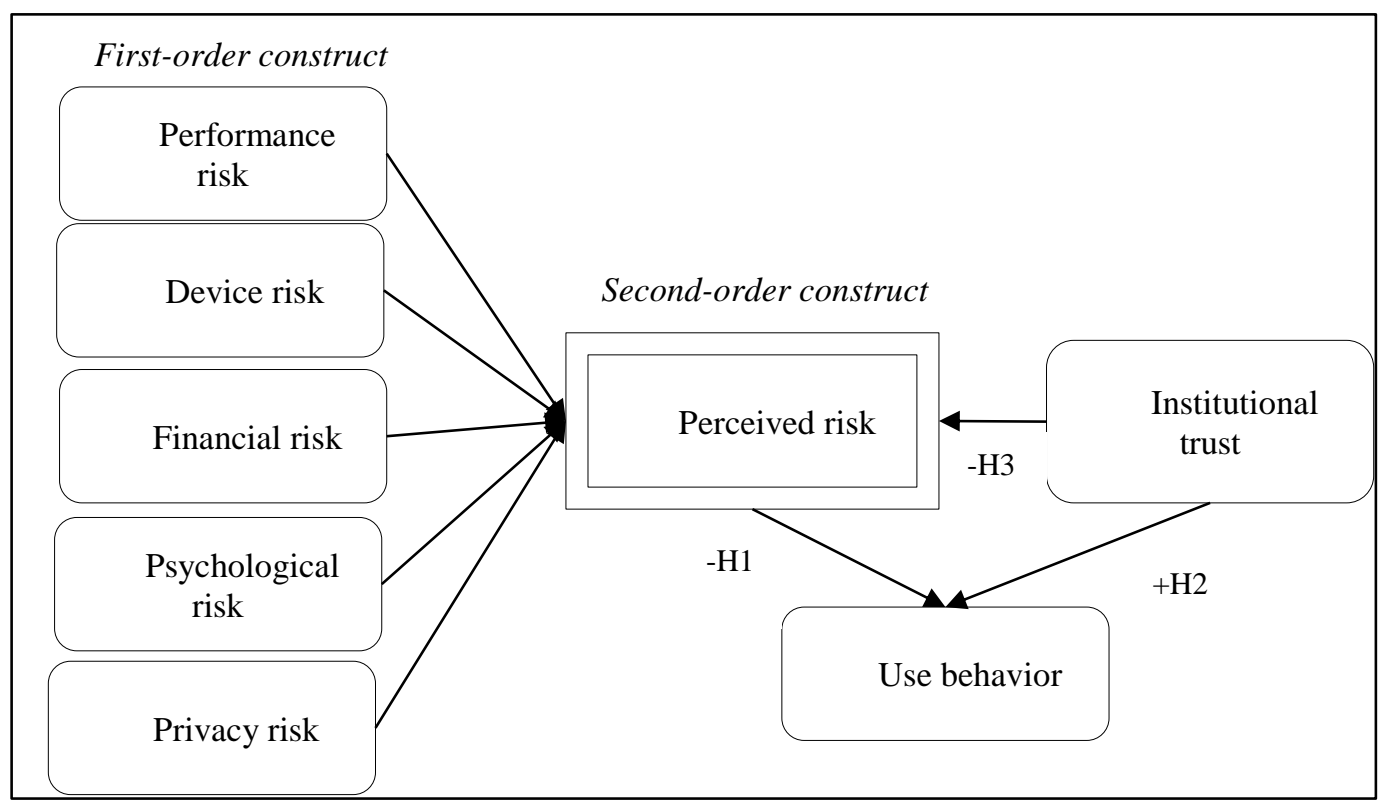

Source: Authors' compilation 


\section{Hypotheses formulation}

\subsection{Perceived risk and use behaviour}

Perceived risk is recognised for its significance in the consumer behaviour literature, which examines the importance of perceived risk in studying the buying decisions of customers who are interested in buying technology products and services (Cunningham, 1967; Mitchell, 1999; Thaker, Pitchay, Thaker, Amin, 2019). From a mobile banking perspective, perceived risk is seen as an individual's expectation of suffering a loss when using mobile banking to perform banking transactions (Cocosila \& Trabelsi, 2016; Fara et al., 2018). As a result, high perceived risk is a major barrier to the adoption of mobile banking. Previous studies have found that perceived overall risk reinforces customer inactivity to adopting various m-commerce innovations such as mobile banking (Arvidsson, 2014; Park \& Tussyadiah, 2016; Poromatikul et al., 2019). Therefore, this study proposes the following hypothesis:

H1: Overall perceived risk will have a significant negative impact on customers' use of mobile banking apps.

\subsection{Institution-based trust and use behaviour}

Institution-based trust plays an important role in reducing the level of risk and hesitation. Indeed, it is a critical aspect in promoting customers' acceptance of mobile banking technology (Maduku, 2016). Earlier studies identify institution-based trust as a significant predictor of customer intention and actual use of technology products and services (Joubert \& Belle, 2009; Hsieh 2015, Maduku, 2016). The study of Zucker (1986) emphasises the significance of institution-based trust in impersonal financial environments such as internet and mobile banking. Based on the foregoing argument, the following hypothesis is proposed:

H2: Institution-based trust will have a significant positive impact on customers' use behaviour with mobile banking apps.

\subsection{Institution-based trust and perceived risk}

The use of mobile banking exposes customers to high levels of risk (such as system hackers and information interception). This raises security concerns and increases customers' reluctance to adopt mobile banking (Zhou, 2012). From the mobile banking app viewpoint, 'institution-based trust' denotes 
to the level of security that customers feel about guarantees and safety nets associated with mobile banking apps. Non-existence of institution-based trust can act as a barrier to customers' adoption of mobile banking apps (Bhattacherjee, 2002). Conversely, if customers believe that institution-based trust exists, their online environment perception of risk decreases (McKnight et al., 2002). Therefore, this study proposes the following hypothesis:

\section{H3: Institutional trust will have a significant negative impact on customer's overall perceived risk.}

\section{Method}

\subsection{Measurement, data collection, and sample}

A structured paper-based questionnaire was used in the study. The items measuring the constructs were adapted from previous related studies. The items measuring perceived risk constructs and firstorder constructs were adapted from Featherman and Pavlou (2003), Kim, Kim and Leong (2005), and Rotchanakitumnuai (2007). The items for measuring the primary institutional trust constructs were adapted from McKnight et al. (2002). All items were measured on a seven-point Likert scale with anchors ranging from 1 ("strongly disagree") to 7 ("strongly agree"). A survey strategy was used to obtain the data through a self-administered paper-based questionnaire. The target population was defined as the banking clients of five South African retail banks (ABSA, Capitec, First National Bank, Nedbank, and Standard Bank). These banks were selected because they are the major banking groups in the country, and all offer banking services on apps.

A non-probability sampling technique in the form of convenience sampling was applied to choose participants. The data was collected through household and office visits. Four hundred questionnaires were distributed to respondents; however, only 352 valid responses were received and used for the analysis, representing an effective response rate of $88 \%$.

\section{Data analysis and procedure}

\subsection{Measurement model evaluation}

The evaluation of the measurement assessed the validity of the formative measures. To achieve this, the model's outer weight, convergent validity, and collinearity of indicators were analysed. In evaluating convergent validity, Cronbach's alpha, composite reliability, and average variance extracted (AVE) were used. The assessment of the significance of the outer weights and the collinearity among the indicators was achieved using the variance inflation factor (VIF). To establish convergent validity, 
Cronbach's alpha for the internal consistency of reliability and the composite reliability should exceed 0.7 (Nunnally, 1978) and the AVEs for each of the constructs should be greater than 0.5 (Hair, Marko \& Ringle, 2018).

The results presented in Table 1 indicate that the Cronbach's alpha and composite reliability estimates all exceeded the 0.7 recommended level. Similarly, the AVEs were greater than the 0.5 threshold, with the lowest AVE score for actual use behaviour being 0.624, further confirming convergent validity. Accordingly, the formative constructs were empirically established to be valid and reliable.

Table 1: Convergent validity assessment of formative constructs

\begin{tabular}{|l|l|l|l|}
\hline & Cronbach's alpha & $\begin{array}{l}\text { Composite } \\
\text { reliability }\end{array}$ & $\begin{array}{l}\text { Average variance } \\
\text { extracted (AVE) }\end{array}$ \\
\hline $\begin{array}{l}\text { Institution-based } \\
\text { trust }\end{array}$ & 0.949 & 0.963 & 0.867 \\
\hline Use behaviour & 0.803 & 0.869 & 0.624 \\
\hline Perceived risk & 0.756 & 0.882 & 0.777 \\
\hline
\end{tabular}

Following the recommendation of Hair et al. (2018), the validity of the formative constructs entailed the assessment of the significance of the outer weights and the collinearity among the indicators. This was achieved using the variance inflation factor (VIF). The results in Table 2 suggest that the indicators of perceived risk are all significant, with VIF values below the critical threshold of 5 (Hair et al., 2018). Similar empirical support is obtained for the validity of the first-order measures of perceived risk (device risk, financial risk, performance risk, privacy risk, and psychological risk). 
Dimensions of perceived risk of mobile banking apps: An empirical ..

P. Thusi, D. Maduku

Table 2: Convergent validity assessment of formative constructs

\begin{tabular}{|l|l|l|l|}
\hline Second-order formative construct & $\begin{array}{l}\text { Outer } \\
\text { weight }\end{array}$ & $\begin{array}{l}\text { T } \\
\text { Statistics }\end{array}$ & VIF \\
\hline Device risk & 0.219 & 18.457 & 3.450 \\
\hline Financial risk & 0.286 & 19.510 & 3.031 \\
\hline Performance risk & 0.222 & 17.053 & 2.958 \\
\hline Privacy risk & 0.200 & 15.236 & 3.365 \\
\hline Psychological risk & 0.145 & 9.564 & 2.941 \\
\hline
\end{tabular}

First-order formative construct

\begin{tabular}{|l|l|l|l|l|}
\hline Device risk & DR1 & 0.331 & 3.509 & 3.653 \\
\hline & DR2 & 0.333 & 3.596 & 3.953 \\
\hline & DR3 & 0.413 & 5.775 & 2.855 \\
\hline Financial risk & FR1 & 0.319 & 3.257 & 3.917 \\
\hline & FR2 & 0.280 & 3.192 & 3.382 \\
\hline & FR4 & 0.152 & 2.663 & 2.913 \\
\hline $\begin{array}{l}\text { Performance } \\
\text { risk }\end{array}$ & FR5 & 0.323 & 3.686 & 4.308 \\
\hline & PM1 & 0.587 & 12.058 & 2.225 \\
\hline & PM4 & 0.119 & 2.079 & 2.612 \\
\hline Privacy risk & PR1 & 0.387 & 6.280 & 3.043 \\
\hline & PR3 & 0.216 & 1.998 & 4.359 \\
\hline $\begin{array}{l}\text { Psychological } \\
\text { risk }\end{array}$ & PR5 & 0.272 & 2.454 & 4.086 \\
\hline & & 0.564 & 5.526 & 4.312 \\
\hline & PY3 & 0.475 & 5.463 & 4.747 \\
\hline & PY4 & 0.554 & 6.406 & 4.747 \\
\hline
\end{tabular}

\section{Structural equation model analysis}

After confirming the validity of the measurement model, the hypothesised structural paths in the research model were estimated. The analysis of the structural model was accomplished using 
the partial least squares structural equation modelling technique, using SmartPLS 3. The results of the PLS-SEM of the structural model analysis are depicted in Figures 2 and 3.

Figure 2: Structural model analysis with path coefficients and R2 estimates

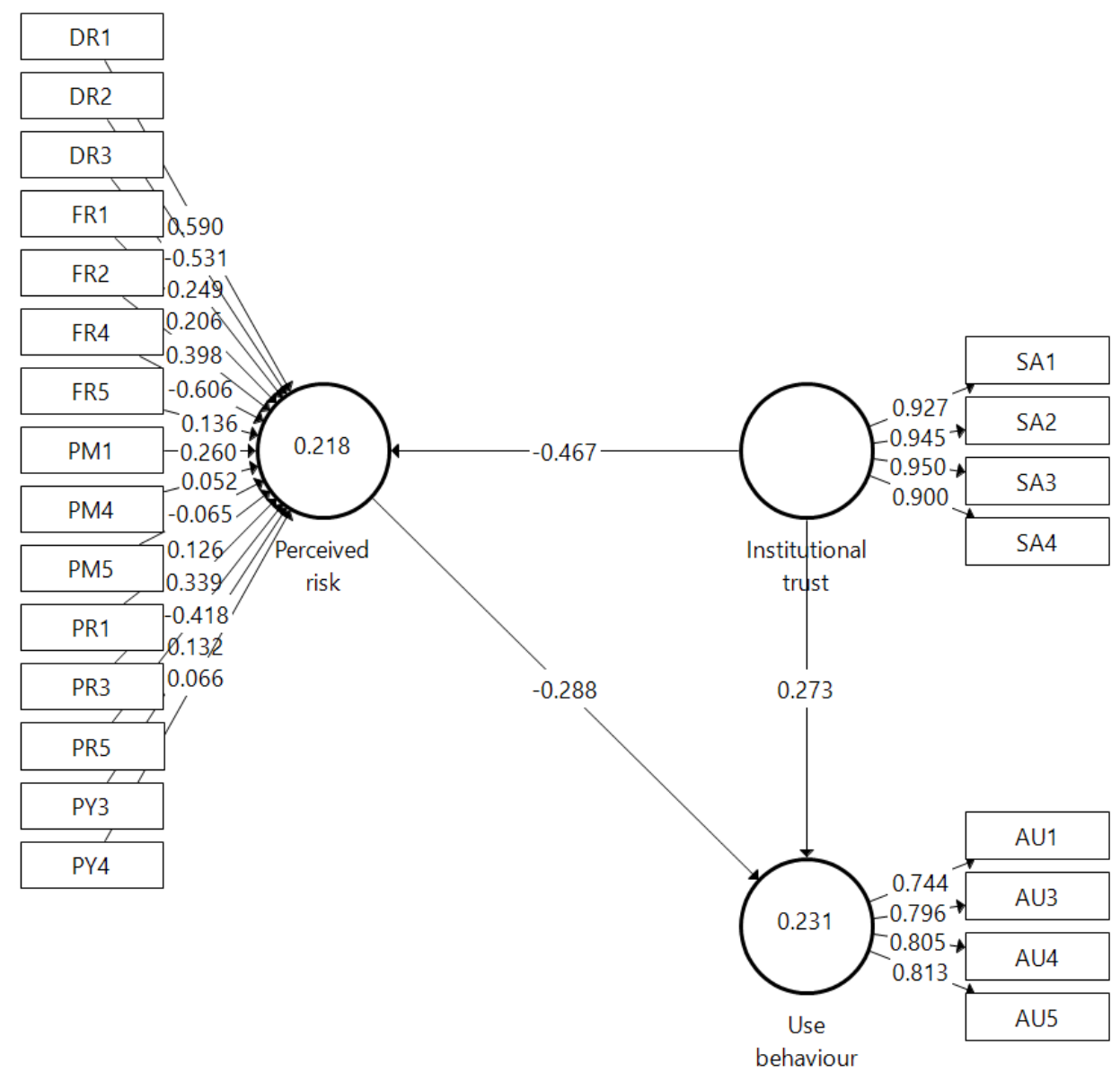


Figure 3: Structural model analysis with path coefficients and $P$ values

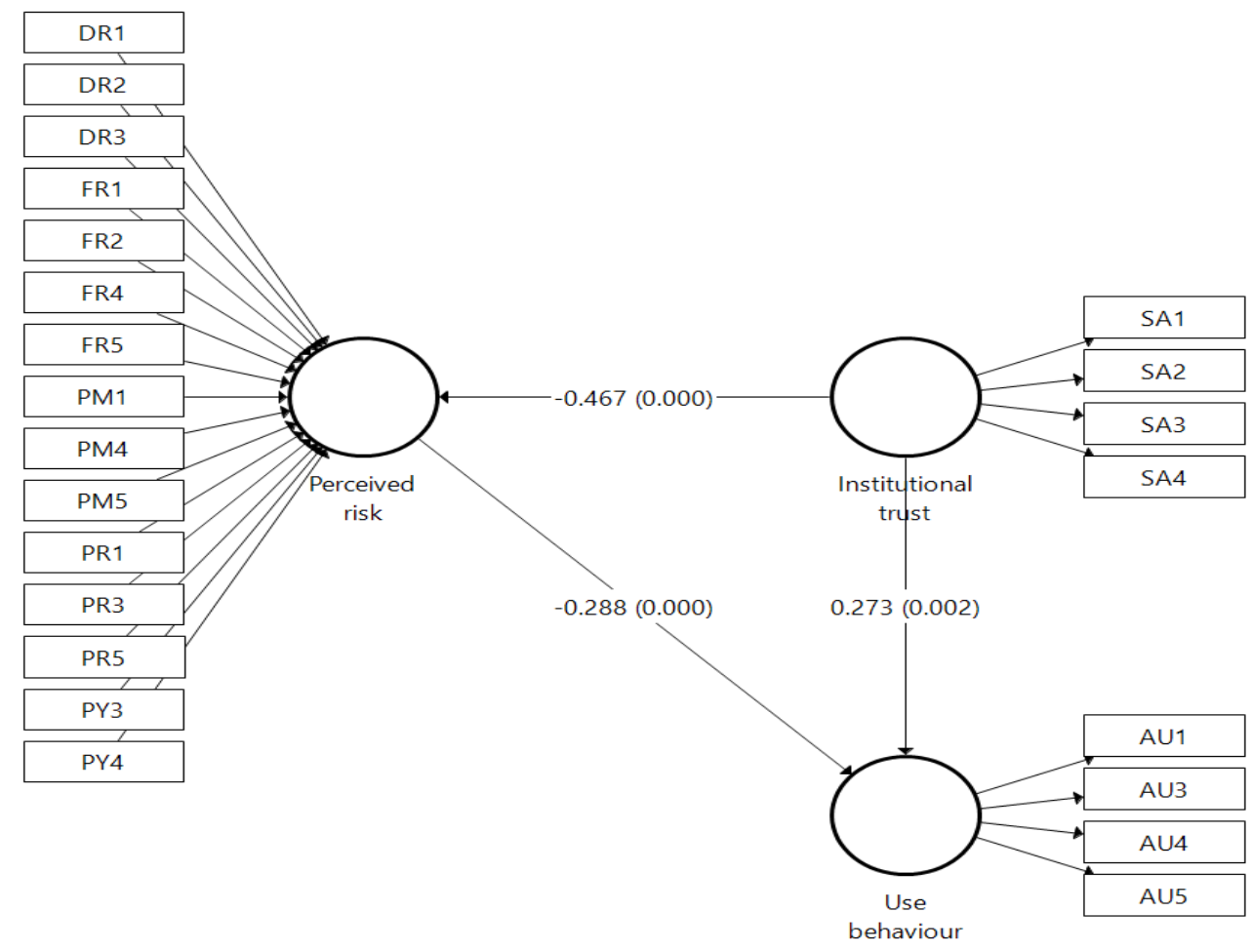

The results of the structural model analysis indicate that perceived risk has a strong and a negative influence on customers use of mobile banking apps, institution-based trust is significant and positively associated with the use of mobile banking apps and institution-based trust is significant and negatively associated with perceived risk. According to the results, perceived risk $(\beta=-0.288, p<0.001)$ has a significant negative influence on mobile banking app use behaviour, this implies that if customer believe that using mobile banking app is risky, they will not use it. Institution-based trust $(\beta=0.273, p$ $<0.001$ ) has significant positive effects on the use of mobile banking apps, this implies that if customers have confidence on the level of security and safety nets related to mobile banking apps, they are more likely to use the app; and institution-based trust $(\beta=-0.467, p<0.001)$ has a significant negative association with customers' perception of the overall risk of using mobile banking apps, this means that if customers believe that institution-based trust exists, their mobile banking app perception of risk decreases . The results from the SEM provide support for $\mathrm{H} 1, \mathrm{H} 2$, and $\mathrm{H} 3$. 


\section{Discussion and implications}

The results confirm a significant negative association between perceived risk and use behaviour (H1). Therefore, it can be concluded that users' perceived risk associated with mobile banking apps is a barrier to the use of this technology, these results are in line with previous studies that observed a negative relationship between perceived risk and use behaviour of technology products (LiébanaCabanillas, Muñoz-Leiva \& Sánchez-Fernández, 2013; Roy, Balaji, Kesharwani \& Sekhon, 2017). Furthermore, the results of this study suggest that institution-based trust has a significant positive effect on the use of mobile banking apps (H2). This suggests that customers will adopt mobile banking apps if they trust the systems of the mobile banking apps as well as the banking institutions offering the service, these findings are in line with the results of $\mathrm{Gu}$, Lee and Suh (2010). This study further revealed a strong negative association between customers' perceived risk of using mobile banking apps and institution-based trust (H3). This implies that customers institution-based trust is a critical factor that decreases customers' perceived risk of using mobile banking apps.

\section{Conclusion}

The results from this study will allow banks and other financial service providers to develop effective strategies that will encourage customers to use mobile banking apps. This study revealed a negative relationship between perceived risk and use behaviour, this shows that mobile banking app users' risk anxieties have a negative impact on their actual use of this innovation. Thus, banks need to moderate the risk fears by offering new and advanced safety measures that assuage this risk. Also, the study has revealed a strong negative association between institution-based trust and perceived risk. Therefore, South African retail banks should introduce state-of-the-art security and safety measures to gain the trust of their customers. 


\section{Reference list}

Alalwan, A. A., Dwivedi, Y. K., Rana, N. P. \& Williams, M. D. (2016). Consumer adoption of mobile banking in Jordan: Examining the role of usefulness, ease of use, perceived risk and self-efficacy. Journal of Enterprise Information Management, 29(1), 118-139.

Arvidsson, N. (2014). Consumer attitudes on mobile payment services - results from a proof of concept test. International Journal of Bank Marketing, 32(2), 150-170.

Bain \& Company. (2015). Mobile now rules in banking. Available: https://www.bain.com/insights/mobile-now-rules-in-banking-forbes/ [Accessed 12 June 2019].

Banking Association South Africa (BASA). (2017). Association and industry overview. Available: http://www.banking.org.za/about-us/association-overview. [Accessed 11 May 2019].

Baptista, G. \& Oliveira, T. (2015). Understanding mobile banking: The unified theory of acceptance and use of technology combined with cultural moderators. Computers in Human Behavior, 5(1), 418430 .

Bhattacherjee, A. (2002). Individual trust in online firms: Scale development and initial test. Journal of Management Information Systems, 19, 211-242.

Business Tech. (2014) Africa leads in mobile banking. Available: https://businesstech.co.za/news/mobile/52025/africa--leads--in--mobile--banking/ [Accessed 08 June 2019].

Chavali, K. \& Kumar, A. (2018). Adoption of mobile banking and perceived risk in GCC. Banks and Bank Systems, 13(1), 72-79.

Cocosila, M. \& Trabelsi, H. (2016). An integrated value-risk investigation of contactless mobile payments adoption. Electronic Commerce Research and Applications, 20(1), 159-170.

Cruz, P., Neto, L. B. F., Murioz-Gallego, P. \& Laukkanen, T. (2010). Mobile banking rollout in emerging markets: Evidence from Brazil. International Journal of Bank Marketing, 28(5), 342-371.

Cunningham, S. M. (1967). The major dimensions of perceived risk. Risk Taking and Information Handling in Consumer Behavior, 8(1), 82-108.

Deloitte. (2013). Global mobile consumer survey. Available: http://www.iabeurope.eu/files/1913/8574/2118/deloitte-nl-global-mobile-consumer-survey.pdf [Accessed 03 April 2019].

Erl, T., Gee, C., Chelliah, P. R., Kress, J., Normann, H., Maier, B. \& Wik, P. (2014). Next generation SOA: A concise introduction to service technology \& service-orientation. New York: Pearson Ed F Featherman, M. \& Pavlou, P.A., (2002). Predicting E-Services Adoption: A Perceived Risk Facets Perspective. International Journal of Human-Computer Studies, 59, 4, 451-474, 2002. 
Featherman, M. S. \& Pavlou, P. A. (2003). Predicting e-services adoption: A perceived risk facets perspective. International Journal of Human-Computer Studies, 59, 451-474.

Fenu, G. \& Pau, P. L. (2015). An analysis of features and tendencies in mobile banking apps. The 12th International Conference on Mobile Systems and Pervasive Computing. FNC/MobiSPC.

Fjermestad, J. \& Robertson, N.C. (2015). Electronic customer relationship management. London: Routledge.

Gao, L. \& Waechter, K. A. (2015). Examining the role of initial trust in user adoption of mobile payment services: An empirical investigation. Information Systems Frontiers, 1-24.

Grewal, D., Gotlieb, J. \& Marmorstein, H. (1994). The moderating effects of message framing and source credibility on the price - perceived risk relationship. Journal of Consumer Research, 21(1),145153.

Gu, J. C., Lee, S. C. \& Suh, Y. H. (2009). Determinants of behavioral intention to use mobile banking. Expert Systems with Applications, 36(9), 11605-11616.

Hair, J. F. Jr, Marko, R. J. S. \& Ringle, C. (2018). When to use and how to report the results of PLSSEM. European Business Review,31(1),2-24.

Huang, L., Ba, S. \& Lu, X. (2014). Building online trust in a culture of Confucianism? The impact of process flexibility and perceived control. ACM Transactions on Management Information Systems (TMIS), 5(1), 1-23.

Joubert, J. \& Belle, J. (2009). The importance of trust and risk in m-commerce: A South African perspective. PACIS 2009 - 13th Pacific Asia Conference on Information Systems: IT Services in a Global Environment.

Khasawneh, M. H. A. (2015). A mobile banking adoption model in the Jordanian market: An integration of TAM with perceived risks and perceived benefits. Journal of Internet Bank Commerce, 20(3),1-13. Kim, L. H., Kim, D. \& Leong, K. J. (2005). The effect of perceived risk on purchase intention in purchasing airline tickets online. Journal of Hospitality \& Leisure Marketing, 2005(2), 33-53.

Lee, M. C. (2009). Factors influencing the adoption of internet banking: An integration of TAM and TPB with perceived risk and perceived benefit. Electronic Commerce Research and Applications, 8(3), 130-141.

Li, H., Jiang, J. \& Wu, M. (2014). The effects of trust assurances on consumers' initial online trust: A two stage decision-making process perspective. International Journal of Information Management, 34(3), 395-405. 
Maduku, D. K. (2016). The effect of institutional trust on internet banking acceptance: Perspectives of South African banking retail customers. South African Journal of Economic and Management Sciences (SAJEMS), 19(4), 533-548.

McKnight, D. H., Choudhury, V. \& Kacmar, C. (2002). Developing and validating trust measures for e-commerce: An integrative typology. Information Systems Research, 13, 334-359.

Moser, F. (2015). Mobile banking: A fashionable concept or an institutionalized channel in future retail banking? Analysing patterns in the practical and academic mobile literature. International Journal of Banking Marketing, 33, 167-177.

Park, S. \& Tussyadiah, I. P. (2016). Multidimensional facets of perceived risk in mobile travel booking. Journal of Travel Research, 34(5), 636-652.

Pavlou, P. A. \& Gefen, D. (2004). Building effective online marketplaces with institution-based trust. Information Systems Research, 15(1), 37-59.

Rotchanakitumnuai, S. \& Speece, M. (2003). Barriers to internet banking adoption: A qualitative study among corporate customers in Thailand. International Journal of Bank Marketing, 21(6/7), 312-323.

Sampaio, C. H., Ladeira, W. \& Santini, F. (2017). Apps for mobile banking and customer satisfaction: A cross-cultural study. International Journal of Bank Marketing, 35(7), 133-115.

Shaikh, A. A. \& Karjaluoto, H. (2015). Mobile banking adoption: A literature review. Telematics and Informatics, 32(1), 129-142.

Tan, E. \& Lau, J. (2016). Behavioural intention to adopt mobile banking among the millennial generation. Young Consumers, 17(1), 18-31.

Zhou, T. (2012). Understanding users' initial trust in mobile banking: An elaboration likelihood perspective. Computers in Human Behavior, 28(4), 1518-1525.

Zucker, L. G. (1986). Production of trust: Institutional sources of economic structure, 1840-1920. Research in Organizational Behavior, 8, 53-111. 